\title{
SMARCA1 wt Allele
}

National Cancer Institute

\section{Source}

National Cancer Institute. SMARCA1 wt Allele. NCI Thesaurus. Code C52108.

Human SMARCA1 wild-type allele is located in the vicinity of Xq25 and is approximately 78 $\mathrm{kb}$ in length. This allele, which encodes probable global transcription activator SNF2L1 protein, is involved in both transcriptional regulation and chromatin remodeling. 